\title{
Alternative Corrective Measures Used in Managing Student Behavior Problems in Secondary Schools in Bondo Sub County, Kenya
}

\author{
Pamela Awuor Onyango \\ Jaramogi Oginga Odinga University of Science and Technology \\ * Dr. Pamela Raburu \\ Department of Psychology, Jaramogi Oginga Odinga University of Science and Technology \\ P.O.BOX 210, Bondo, 40601, Kenya; praburu@jooust.ac.ke \\ Dr. Peter J.O. Aloka
}

Department of Psychology, Jaramogi Oginga Odinga University of Science and Technology

Doi:10.5901/mjss.2016.v7n1p527

\section{Abstract}

The purpose of the study was to identify alternative corrective measures used by teachers to manage students' behavior problems in secondary schools. The study was informed by Assertive Discipline Model and Thorndike's Behavior Modification Theory. Mixed methods research approach was used and with it, concurrent triangulation design was adopted. Target population of the study was composed of 308 teachers from a total number of 34 schools that had 34 Heads of Guidance and Counseling, 34 Deputy Principals and 240 classroom teachers. Krejcie \& Morgan sample size determination table and stratified random sampling technique was used to sample 28 Deputy Principals from a total number of 34 deputy principals, 28 Heads of Guidance and Counseling from a total number of 34 and 152 teachers from a total of 240. Pilot study was done in three schools that didn't participate in the actual study to determine reliability of the instruments and split half method was used to ascertain a reliability coefficient of 0.871 . Face validity of the instruments was ascertained by pilot testing the questionnaires and also by seeking expert judgment by university lecturers. Data was collected using questionnaires, in-depth interviews and document analysis guides. Quantitative data was analyzed using basic descriptive statistics and inferential statistics. Qualitative data from interviews were analyzed using thematic analysis. The study findings revealed that alternative corrective measures like guidance and counseling, manual work, temporary withdrawal from class, withdrawal of privileges and suspension were used in managing student behavior problems. However, it was established that use of rules and detention were not preferred as alternative methods of managing student behavior problems.

Keywords: alternative corrective measures, student behavior problems, secondary school, students, management

\section{Introduction}

Teaching in schools goes beyond gathering students for learning only but also in addressing behavior problems of students (Nakpodia, 2012). Schools face more complex acts of misconduct by students than previously experienced (Mugabe and Maphosa, 2013). While some teachers argue that punishment is the answer, others prefer instilling discipline among learners (Mugabe and Maphosa, 2013).

In South Africa, the national government has taken a number of measures to implement the prohibition of corporal punishment in schools (Soneson, 2005). Staff members have been appointed at the national and provincial Departments of Education to ensure adherence to the prohibition within the educational system (Soneson, 2005). The South African national department has also published a manual for teachers on alternatives to corporal punishment, which has been distributed widely together with a guide for persons facilitating training on the manual (Soneson, 2005).

Muneja (2013) in Tanzania observes that many teachers and parents feel that a prohibition of corporal punishment is causing a decline of discipline in the schools. There is a dual problem of too much punishment without alternatives or the absence consequences for poor behavior which leaves many teachers confused and ultimately apathetic about putting any sort of boundaries for the expected behavior amongst students.

In Kenya, student behavior problems constitute barriers to learning, which makes school unsafe and negatively impact on learning and overall well- being of students and teachers (Aloka \& Bojuwoye, 2013). Student discipline has 
been found to have a direct impact on students' academic performance (Borkan, Cappa, Figueiredo and Loadman, 2003). The ill disciplined behaviors of secondary school students have caused public outcry and continued to feature more prominently in the national agenda of Kenya (Aloka and Bojuwoye, 2013). Ajowi and Simatwa (2010) reiterate that unrest has continued in secondary schools with a new dimension and are not only violent and destructive but they are also premeditated and planned and have caused maximum harm to human life.

Schools in Bondo Sub County of Kenya experience cases of defiant students who confront their teachers and destroy school property. In response to the escalating student behavior problems in schools, corporal punishment was banned in Kenyan schools in the year 2001. Since the ban, school discipline has been deteriorating to such a level that the school system may soon become unmanageable (Kindiki, 2009). Faced with this challenge, teachers were instructed by the Ministry of Education to adopt other measures aimed at curbing the various cases of indiscipline in learning institutions. Among these has been the establishment of guidance and counseling units in all schools, effective teaching methods and inclusion of learner in the making of school rules, among others (MOEST, 2005). In spite of these efforts, there have been several reported cases of challenges faced by teachers in the use of alternative disciplinary patterns as opposed to corporal punishment in schools (Alawo, 2011).

\subsection{Objective of the Study}

The objective of the study was to identify alternative corrective measures used by teachers in managing students' behavior problems.

\section{Theoretical Framework and Literature Review}

\subsection{Theoretical Framework}

This study was informed by two theories; Assertive Discipline Model by Lee and Marlene Canter (Canter \& Canter 2001) and behavior modification theory advanced by Thorndike (Corsine, 1987).

\subsubsection{Assertive Discipline Model}

The Assertive Discipline Model was developed to address significant issues with classroom management which were affecting student learning and achievement. The theory asserts that, the teacher should create and teach a discipline plan with 4-5 rules and specific consequences by first identifying rules and expectations and presenting them to students, ensuring that they are understood. Further, the teacher is required to use positive repetition to reinforce the rules by focusing on reinforcing positive behaviors rather than punishing the negative ones (Canter \& Canter 2001).

Assertive Discipline Theory according to Canter \& Canter (2001) suggests a five-step discipline hierarchy of escalating consequences when rules are broken. The first infraction involves giving warning to the student; the second infraction gives the student a ten-minute time out while in the third one, the student is given a fifteen-minute time out. In the fourth infraction, the student's parents are called. Finally, the fifth sanction requires that the student is sent to the principal's office.

\subsubsection{Thorndike's Behavior Modification Theory}

Another theory that informs the study is Thorndike's Behavior Modification Theory (Rosenhan \& Seligman, 1995) which addresses human behavior through the law of effect. According to this theory, learning depends on the events that occur after certain behavior and that learning what to do is gradual, not insightful. According to the law of effect, when in a given stimulus situation, a response is made and followed by a positive consequence, the response will tend to be repeated (Busienei, 2012). When followed by a negative consequence, it will tend not to be repeated. Thorndike advanced the law of effect according to which behaviors that are rewarded tend to persist while those that are followed by discomfort or punishment tend to diminish (Busienei, 2012).

\subsection{Literature Review}

Yaworski (2012) investigated the effectiveness of corporal punishment in maintenance of student behavior in the United States and data was collected by use of multiple articles gathered from educational and psychological journals. The study 
established that throughout the United States, classrooms had been dealing with a steady change of disciplinary options over the years. The current study bridged this gap by carrying out the study in Kenya and was empirical in nature.

Golkar, Alavijeh, Ghasempoor, Amiri and Zarrin (2012) carried out a study on qualitative study styles and methods of disciplinary measures used in middle schools to provide appropriate guidance in Iran. The article examined the amount of using a wide range of different techniques and approaches including preventive; imperative; corrective and frivolous by the teachers. The current study attempted to bridge this gap by carrying out such a study in secondary schools.

Marais \& Meier (2010) investigated disruptive behavior in the foundation phase of schooling in South Africa. The results of the study indicated that the key to addressing disruptive behavior lies within a systems theory approach which involves a shift of focus from objects to relationships and from individuals to communities.

The influence of discipline management by head teachers on students' academic performance was investigated in Uganda by Kiggundu (2009). The study concluded that much as school rules helped in controlling students, their awareness was lacking among students. Punishments were also found to be poorly administered to students, which created chaos in schools characterized with school property destruction, thus affecting students' general academic performance. There was need to establish the situation in public schools in Kenya. The current study attempted to fill the gap in literature by adopting mixed methods approach, and conducting the study in Kenya.

Kipkoech (2014) investigated alternative methods to corporal punishment in managing students discipline in secondary schools in Bomet District of Kenya. The study was guided by the theory of Stage Theories of Behavior Change by Proschaska and Diclemante (1986). The study showed that there was a lot of negative change in student discipline with the outlawing of corporal punishment in schools. Teachers also reported that they faced challenges in dealing with students' discipline in schools without corporal punishment.

\section{Research Methodology}

\subsection{Research Design}

This study adopted mixed methods approach which includes both quantitative and qualitative methods (Creswell, 2014). The current study was balanced on both qualitative and quantitative approaches because both were used to establish the alternative corrective measures in managing student behavior problems. Within the mixed methods approach, Concurrent Triangulation approach was used (Rothbauer, 2008). The methodology used is significant to this study because the data obtained is for both qualitative and quantitative analysis. Therefore, a mixed method research approach.

\subsection{Study Participants}

The study population comprised of 34 Heads of Guidance and Counseling, 34 Deputy Principals and 240 teachers, which gave a target population of 308 . Bondo Sub County is composed of sub county schools, county schools and one national school. The sub county schools had 141 teachers, 26 Deputy Principals and 26 Heads of Guidance and Counseling. The county schools had 49 teachers, 7 Deputy Principals and 7 Heads of Guidance and Counseling. There were 50 teachers, 1 Deputy Principal and 1 Head of Guidance and Counseling in the only national school in the Sub-County.

\subsection{Research Instruments}

Questionnaires, interview schedules and document analysis guides were used for data collection in the study. The questionnaire was employed by the researcher due to its efficacy and ease of construction (Cohen, Manion \& Morrison, 2007). Interview schedules allowed the researcher to obtain information that could not be directly observed. All the interviews were audio-taped and transcribed verbatim for analysis by the researcher to allow for immersion in the data and to maintain coherence and connections in the content (Oso \& Onen , 2011). Document Analysis Guides obtained from secondary schools enabled the researcher to access data conveniently and to save time.

\subsection{Data Collection Procedures}

Data collection procedure began after the proposal had been accepted by the university supervisors. An introductory letter was acquired from the Board of Post Graduate Studies of Jaramogi Oginga Odinga University. Permission to collect data was sought from the National Council of Science and Technology. Ethical issues were considered. This included privacy of possible and actual participants, voluntary nature of participation and maintenance of confidentiality of data 
provided. Anonymity was censured by not using real names of participants, for example HOD 4 (Head of Department, 4) DP1 (Deputy Principal, 1). Questionnaires were issued to sampled teachers while interviews were held with deputy principals and heads of guidance and counseling and the responses tape recorded. Document analysis guides from secondary schools in form of major offences book and minor offences book were also used to gather information.

\subsection{Data Analysis}

Data was analyzed quantitatively and qualitatively.

\subsubsection{Quantitative Data Analysis}

Quantitative data analysis involved the use of descriptive and inferential statistics with the aid of Statistical Package for Social Sciences version 22. Data on alternative corrective measures used in managing student behavior problems was analyzed through the use of descriptive statistics.

\subsubsection{Qualitative Data Analysis}

Qualitative data from interviews and documents was analyzed using Thematic Analysis. The current research followed the principles of thematic analysis according to (Braun and Clarke, 2006). Thematic analysis is not grounded in any particular theoretical and epistemological framework and can therefore, be applied across a wide range of qualitative research approaches, making it flexible (Braun and Clarke, 2006).Verbatim quotations from interviews showing themes and codes that emerged from interviews were transcribed and coded, as was in Raburu ( 2015).

\section{Findings and Discussion}

In order to establish alternative corrective measures used by teachers in managing students' behavior problems, the respondents were asked to score on each statement based on their perception of the statement in regard to alternative methods to punishment as used by teachers. The statements in the questionnaire were linked to the construct related to issues that had bearing on methods of punishment as used by teachers in secondary schools. The responses are presented on Table 4.1

Table 4.1: Responses on alternative methods used in managing student behaviour problems

\begin{tabular}{|c|c|c|c|c|c|}
\hline Method & Not at all & Very little extent & Moderate exten & Great extent & Very great extent \\
\hline Sending the learner to detention & $186(100 \%)$ & $0(0.0 \%)$ & $0(0.0 \%)$ & $0(0.0 \%)$ & $0(0.0 \%)$ \\
\hline Expelling the learner & $126(67.7 \%)$ & $60(32.3 \%)$ & $0(0.0 \%)$ & $0(0.0 \%)$ & $0(0.0 \%)$ \\
\hline Sending the learner to the principal & $75(40.3 \% 0$ & $111(59.7 \%)$ & $0(0.0 \%)$ & $0(0.0 \%)$ & $0(0.0 \%)$ \\
\hline Sending the learner out of class & $111(59.7 \%)$ & $51(27.4 \%)$ & $0(0.0 \%)$ & $0(0.0 \%)$ & $24(12.9 \%)$ \\
\hline Reasoning with the learner during the lesson & $123(66.1 \%)$ & $63(33.9 \%)$ & $0(0.0 \%)$ & $0(0.0 \%)$ & $0(0.0 \%)$ \\
\hline Approaching school counselor & $102(54.8 \%)$ & $84(45.2 \%)$ & $0(0.0 \%)$ & $0(0.0 \%)$ & $0(0.0 \%)$ \\
\hline Giving positive reinforcement & $111(59.7 \%)$ & $51(27.4 \%)$ & $24(12.9 \%)$ & $0(0.0 \%)$ & $0(0.0 \%)$ \\
\hline Giving extra homework & $24(12.9 \%)$ & $102(54.8 \%)$ & $0(0.0 \%)$ & $24(12.9 \%)$ & $36(19.4 \%)$ \\
\hline Giving physical task around the school & $126(67.7 \%)$ & $36(19.4 \%)$ & $24(12.9 \%)$ & $0(0.0 \%)$ & $0(0.0 \%)$ \\
\hline Making learners stay in at break/ after school & $162(87.1 \%)$ & $0(0.0 \%)$ & $24(12.9 \%)$ & $0(0.0 \%)$ & $0(0.0 \%)$ \\
\hline Depriving the learner of an enjoyable activity & $60(32.25 \%)$ & $0(0.0 \%)$ & $0(0.0 \%)$ & $24(12.9 \%)$ & $78(41.9 \%)$ \\
\hline Management of student behavior through use of rules & $111(59.7 \%)$ & $24(12.9 \%)$ & $0(0.0 \%)$ & $0(0.0 \%)$ & $51(27.4 \%)$ \\
\hline Teachers acting as role models & $51(27.4 \%)$ & $24(12.9 \%)$ & $36(19.4 \%)$ & $0(0.0 \%)$ & $75(40.3 \%)$ \\
\hline The use of external resource personnel & $75(40.3 \%)$ & $27(14.5 \%)$ & $0(0.0 \%)$ & $0(0.0 \%)$ & $60(32.3 \%)$ \\
\hline Guidance and counseling & $27(14.5 \%)$ & $0(0.0 \%)$ & $24(12.9 \%)$ & $0(0.0 \%)$ & $135(72.6 \%)$ \\
\hline
\end{tabular}

Table 4.1 shows responses on alternative methods used in managing student behavior problems. The study findings from Table 4.1 revealed that several alternative methods were used in managing student behavior in schools. However, the frequency of use of these alternative methods varies in degree. While $19.4 \%$ of teachers give homework, $32.3 \%$ use external resource personnel and $41.9 \%$ deprive the learner of an enjoyable activity. Some of methods identified include expulsion, suspension, detention, use of guidance and counseling, giving physical tasks, sending learner out of class and withdrawing rewards, among others, as indicated in Table 4.1. 
It emerged from the study findings that most teachers preferred using guidance and counseling to manage students' behaviour problems in secondary schools in Bondo Sub-County since $72.6 \%$ respondents reported that guidance and counseling was used to a great extent. This implies that guidance and counseling was being used in managing student behavior problems. This finding concurs with Simatwa (2012) in Kenya who established that guidance and counseling was being used in managing student behavior problems in schools. Similarly, Nassey (2012) in New Zealand concurs that teachers overall reported use of classroom based management strategies as well as approaches appropriate to the ecology, culture, climate and ethos of the particular school. Although $27(14.5 \%)$ of the respondents said they never rely on guidance and counseling as an alternative method of managing students' discipline, a significant proportion of the teachers who took part in the study confirmed that to a very great extent they use guidance and counseling as an alternative method to curb indiscipline cases from secondary students. There were 60 (32.3\%) respondents who said that the use of external resource personnel is an effective alternative method of controlling and deterring indiscipline issues in schools, but 75 (40.3\%) of the teachers who took part in this study said external resource personnel was not used in their schools to manage student behavior problems This implies that the teachers who resorted to the use of external resource personnel may have faced challenges in managing student behavior problems. This finding agrees with Yaworski (2012) who reported that even though corporal punishment had been banned and teachers trained on nonviolent methods of managing problem behaviors and how to implement these strategies, classrooms still had multiple behavioral issues. Similarly, Ntuli (2012) established that principals and educators still find themselves in a predicament in applying contemporary disciplinary measures due to a lack of training or minimal training regarding alternatives to corporal punishment. However, in a study conducted by Brown (2013) clear, positive communication between students and teachers was shown to be evident, indicating a number of valuable implications for policy and practice.

The findings from the present study show that, a significant portion (40.3\%) of respondents confirmed that, the most commonly used alternative method of managing learners' behaviour was teachers acting as role models. Teachers are expected to show exemplary conduct and character that students must be encouraged to emulate. However, more than a quarter (27.4\%) of the teachers said use of teachers as a role model could not yield instant change of behaviour, hence it is hardly relied on in their schools. Nevertheless, 24(12.9\%) of the respondents agreed that they used teachers as role models to manage behaviour problems, but to a very little extent. There were $36(19.4 \%)$ of teachers who also agreed that teacher as model was used in their schools to manage student behaviour problems. The use of teachers as role models seems not to have been embraced by teachers as a way of managing student behavior problems since most of them seemed not to support this method. Kiggundu (2009) argues that head teachers should be the role models of discipline if this struggle is to achieve its objectives. Similarly, Ifeoma (2011) confirmed that some effective classroom management techniques include teachers acting as role models.

According to the study findings, 111(59.7\%) of the respondents said management of student behavior through use of school rules in their schools was not at all embraced as an alternative method of behavior change to corporal punishment. Though notwithstanding that assertion, more than a quarter $51(27.4 \%)$ of the teachers who took part in the study said use of school rules as a way of managing students behaviour problems, was applied in their schools. This means school rules were used in managing student behavior problems.

It was established from the current study that, depriving a learner of an enjoyable activity was commonly used as an alternative method for managing behaviour problems in schools. This was confirmed by the majority 78 (41.9\%) of respondents who said they use it to a very great extent and another 24(12.9\%) who said they also use it but to great extent. On the same note, nearly a fifth $36(19.4 \%)$ of the respondents said they give extra homework to learners who engage in defiant behaviour to cool them down. However, 24 (12.9\%) of the respondents refuted the claim that they give extra homework to learners as an alternative method of managing behaviour problems and $102(54.8 \%)$ of the respondents said it is used moderately. However, it emerged from the study findings that, most teachers never make learners stay in at break/ after school to correct behaviour problems, as was observed by 162(87.1\%) of the respondents. It seems teachers did not prefer to deprive learners of activities they enjoyed. Similarly, Umezinwa \& Elendu (2012) observed that making a learner stay back after school dismissal was an unacceptable form of punishment.

The findings of the present study show that, majority 111(59.7\%) of the teachers claimed they never send their learners out of class during lessons in a bid to manage behaviour problems. However, $51(27.4 \%)$ confirmed they use this method nonetheless to very little extent, but $24(12.9 \%)$ of respondents confidently said they use it to a very great extent. This implies the teachers found this method of managing student behavior problems unproductive.

Quantitative data from the present study shows that all the respondents had similar opinion on the issue of detention of the students (100\%) teachers denied that they send students to detentions just to punish those who indulge in delinquency behaviour at school. In addition 75(40.3\%) of the teachers disagreed that they always send the students 
to the principals when the students misbehave in school or class. However, many schools never use expulsion of the students as an alternative method to manage student behaviour problems, as was confirmed by $126(67.7 \%)$ and $60(32.3 \%)$ of teachers who participated in the study. The former had not all while the latter had but to very little extent used expulsion as an alternative method of managing discipline. It appears teachers did not embrace this method of managing student behavior problem. However, Simatwa (2012) argues that headteachers use a wide range of methods in managing student discipline in schools, and this includes expulsion, among others. On the contrary, Kiggundu (2009) argues that school rules and regulations and guidance and counseling should be strengthened instead of expelling students. Similarly, Tshabalala, Ncube and Mapolisa (2014) established that teachers thought that the current student expulsion procedure was very ineffective.

It was also established from the study findings that many 126(67.7\%) teachers do not give students physical task around the school as a corrective measure, and in fact the few teachers (32.3\%) who use physical task as a way of deterrent to rising cases of indiscipline in schools, do it very sparingly. It appears that this wasn't a popular method of managing student behavior problems. Perhaps the teachers found this to be taxing, as observed by Tungata (2006) who established that teachers were not in favor of alternative methods of managing student behavior problems that needed to be supervised by them. This study finding is in line with Maphosa (2011) in South Africa who established that manual labour was perceived by teachers to be punitive in nature.

Qualitative findings were also obtained from in-depth interviews and document analysis guides on the alternative methods of managing behavior problems. The themes identified were: Guidance and counseling, manual work, temporary withdrawal from class, withdrawal of privileges and suspension.

\subsection{Guidance and Counseling}

Makinde (1987) defines the terms 'guidance and counseling' as an interaction process co-joining the counselee, who is vulnerable and who needs assistance and the counselor who is trained and educated to give this assistance. There are many methods of enhancing discipline in secondary school, and guidance and counseling is one of them (Kaguamba and Muola, 2010). Guidance and counseling plays an important role in the management of student behavior problems. Excerpts from an interviewee states: "There is guidance and counseling department in place and the students involved in indiscipline are counseled to help remold their behavior. The students are guided on how to behave, not necessarily on indiscipline cases" [DP, 1]

Findings from the above respondent imply that guidance and counseling was being used in school, and that teachers relied on it in as a suitable method of managing student behavior since they not only used it on indiscipline cases, but also in guiding students generally, on how they ought to behave. Similarly, Mwangi (2014) in Kenya agrees that counseling enhances student discipline through building courage and moral uprightness, thereby inculcating good value and positive attitude towards the development of self discipline that enhances behavior change. The finding was similar to Alemu (2013) in Ethiopia who concurred that guidance and counseling services were being provided in secondary schools in Ethiopia, even though male students' utilization of the services was significantly higher than their female counterparts. However, Kavula (2014) argues that principals' use of alternative disciplinary methods has no significant effect on students' discipline. The use of guidance and counseling in managing student behavior problems was also confirmed by another HOD:

There are general guidance sessions which are not necessarily restricted to when students misbehave, but on particular occasions the students are advised and reminded of school rules. Students who make mistakes are talked to at individual level by the teachers they have fallen out of favor with [HOD, 11].

The study findings therefore imply that guidance and counseling were being used in managing student behavior problems and that the teachers did not only offer guidance and counseling services when students erred, and that students were talked to. Similarly, Brown (2013) in the USA believes in the importance of clear and positive communication between students and teachers. Mwangi (2014) in Kenya too argues that dialogue is a popular reward system that influences discipline in schools. Mwangi (2014) further confirmed that both dialogue and punishment were the most popular reward systems to influence discipline in schools. Parents too worked together with teachers in offering guidance and counseling as was noted by one of the respondents;

Parents are also involved in guiding and counseling the students, and students are sent home to call their parents. The teachers and parents then guide the students. Other students are not necessarily sent home to call their parents but are sent home to be guided by their parents, after which they come back to school [HOD, 6].

The study findings indicate that guidance and counseling services were being offered to the

students, and that parents were also involved in guidance and counseling. Similarly, Samoei (2012) in Kenya 
established that parents were called to school to assist in guiding and counseling their children. Kiggundu (2009) in Uganda also argues that there is need for a strong parent-teacher relationship to address the effects of indiscipline in schools. Mohrbutter (2011) in USA too agreed that parents had a major role to play in the management of student behaviors. However, Ngotho and Zani (2014) argued that the promotion of school discipline was hampered by lack of parent participation in their children's' discipline. Afande (2015) in Kenya also concurs that an effective school counseling and guidance service should encourage the involvement of parents in pupils learning environment and also provide increased opportunities for parents. The use of guidance and counseling in managing student behavior was further confirmed by HOD 9 as was represented in the interview excerpt;

Students with behavior problems are identified by the guidance and counseling department and guided. The identification is done in three ways. First, class teachers are used to identify students with various problems and they are forwarded for guidance and counseling. [HOD, 9].

The findings indicate that teachers play a central role in managing student behavior problems by offering guidance and counseling. This is because guidance and counseling department, the disciplinary committee and the career departments were all made up of teachers. Similarly, Eliamani, Mghweno and Baguma (2014) in Uganda confirmed that teachers were involved in guidance and counseling since they offered guidance and counseling services that were proved to be moderately effective in influencing students' study life. Ifeoma (2011) in Nigeria concurs that teachers' classroom management effectiveness is a powerful motivator of students' learning.

Document analysis guide reported the use of guidance and counseling on students who attempted to commit suicide, those who came to school drunk, those who stole, those who walked up and down during study time and those who engaged in boy-girl relationship. The findings from document analysis imply that guidance and counseling was being used in managing various student behavior problems.

\subsection{Manual Work}

Manual work is physical work, which includes tasks that are basic and not degrading or lowly (Khewu, 2012). In the context of the current study, manual work includes tasks like slashing, cleaning the bathroom, uprooting of tree stumps and so on, which are used in managing student behavior problems. One respondent who confirmed the use of manual work in managing student behavior problems cited; "When students make mistakes, members of the student leadership write down their names and they are given manual work at the time when they are supposed to be free and enjoying their rest'[HOD 8].

The study findings imply that engagement of students through manual work was used in managing student behavior problems. Similarly, Ifeoma (2011) in Nigeria concurs that effective classroom management techniques include among others, constant engagement of students in activities. Another respondent noted that manual work was a suitable way of managing student behavior problems because the work given was equal to the nature of student behavior problems. This is presented in the following interview excerpt;

A student is given manual work that is commensurate to the nature of indiscipline. The students may be given such duties as weeding flowerbeds, transferring firewood from one point to the other, washing the lavatories and kitchen, slashing and cleaning the classroom [DP, 1].

Findings reported above imply that manual work was considered a suitable alternative corrective measure in managing student behavior problems. On the contrary, Umezinwa and Elendu (2012) in Nigeria argue that pupil's fetching of water and washing of school toilet are unacceptable forms of punishment. The current study noted that manual work was used in managing serious offences among students as was cited by DP 3, "Students who engage in serious offences like planning to beat a member of the student leadership are asked to uproot tree stumps."

The findings imply that manual work was used in managing serious student behavior problems. Similarly, Sekuwi and Naluwemba (2014) in Uganda concur that alternatives like manual labour should be employed as alternatives to corporal punishment. Ifeoma (2011) in Nigeria too agrees that effective classroom management techniques include, among others, constant engagement of students in activities and use of innovative instructional strategies. However, Bechuke and Debella (2012) believe that careful planning and implementation strategies and in-service training contributes successfully in managing and modifying challenging learner behavior and ensuring discipline in schools and educating learners in the habit of accountability and responsibility for their actions without using punishment. Document analysis guide established that students who were late to school would either be asked to go for their parents or water flowerbeds. Ones who slept in dormitories not otherwise allocated to them would be made to collect litter around the school gate. Similarly, Maphosa (2011) in South Africa established that manual labor was found to be the most common disciplinary measure used in dealing with major forms of indiscipline in schools. The other alternative corrective measure 
was temporary withdrawal from class (time -out)

\subsection{Temporary Withdrawal from Class (Time -out)}

Nkabinde (2007) defines time -out as sending the learner outside or to another classroom for a specific time where he I she will be with learners he/she is not used to, and this makes some learners feel isolated and may stop misbehaving. In the context of the present study, temporary withdrawal from class meant that students who had engaged in behavior problems were sent out of class temporarily. Temporary withdrawal from class was used in managing student behavior problems, as was cited by one respondent, "Students who engage in indiscipline are asked to stay out of class for a while."[HOD, 1]. students.

Findings from HOD 1 imply that staying out of class for a while was expected to effect behavior change among the

Another respondent who had a similar opinion said, "Students are asked to go out to the field and make noise there, if they were making noise in class." [DP, 2].

Another respondent observed that, "Students who sleep in class are sent out to do some work." [HOD, 7].

All the respondents seem to concur that temporary withdrawal from class was used in managing student behavior problem. Similarly, Ifeoma (2011) in Nigeria concurs that effective classroom management techniques includes, among others, constant engagement of students in activities and use of innovative instructional strategies. Another respondent who used temporary withdrawal from class yet was against the use of this alternative corrective measure said, "Sending out of class is not a good one but sometimes some of us use it." [DP, 7]

All the respondents shared similar opinion that temporary withdrawal was one way of managing student behavior problems. The responses obtained imply that temporary withdrawal was used in managing many student behavior problems even though some of the executors of this method believed it was not beneficial to the learner. The study finding is similar to Umezinwa and Elendu (2012) in Nigeria who concur that teachers view sending pupils out of class as an unacceptable form of punishment. Similarly, Maphosa (2011) in South Africa established that the use of disciplinary measures like sending learners out of classroom is punitive in nature. Anitra (2013) in the USA too observed that negative outcomes for students had been associated with the distribution of exclusionary methods and schools had begun to move toward implementing more positive approaches to correct problem behavior. Suleiman, Hussain, Akhtar (2013) in Pakistan recommend that there is need for special training program regarding management of classroom disruptive behavior to equip existing teachers with modern techniques to conduct and manage disruptive behavior properly. The other alternative corrective measure was withdrawal of privileges.

\subsection{Withdrawal of Privileges}

Withdrawal of privileges means depriving one of an intentional award serving as a symbolic approval of desirable behavior (Kilonzo, 2013). The current study noted that students who exhibited behavior problems were denied certain privileges with the aim of achieving behavior change in them, as was presented in the following interview excerpt;

Students who engaged in behavioral problems were denied privileges. For instance, a member of the student leadership was demoted for being a persistent latecomer while others were denied tea for failing to carry out duties allocated to them [DP, 7].

Use of withdrawal of privileges in managing student behavior problems was also cited by HOD 11, "Students who misbehave are denied the opportunity to do what they would like to do, like going to play in the field and are made to do more class work instead." [HOD, 11]

It was established through document analysis guide that a student was demoted from student leadership after vandalizing a fellow student's suitcase with an intention of stealing. Further, students who were members of the student council and were engaged in boy-girl relationship were relieved of their duties as a form of punishment. Members of the student council who were involved in theft were also demoted.

The findings from the respondents and the document analysis imply that withdrawal of privileges was used in managing student behavior problems. Similarly, Maphosa (2011) in South Africa established that withdrawal of privileges like demotion was commonly used in managing major forms of student behavior problems. Even though the findings 
indicated that withdrawal of privileges was used in managing behavior problems, the method didn't appear to effect behavior change uniformly among students since those who were not in student leadership would not suffer demotion even if they committed the same offence as those in leadership. Similarly, Kiggundu (2009) argues that there is need for a uniform discipline code which will assist parents, students and other stakeholders to appreciate the role of punishment in schools. Inkoom (2010) in Ghana also believes that praising of well behaved students at school gatherings and writing of good comments in the termly reports could be used to promote discipline in the school. Simatwa (2012) too concurs that rewards were used in managing student discipline in schools even though he further states that the effectiveness of each method depends on the traditions of schools and their environments. The other alternative corrective measure was suspension.

\subsection{Suspension}

Suspension is a mandatory leave assigned to students as a form of punishment that can last anywhere from one day to several weeks, during which time the child cannot attend regular lessons (Ajibola, Lukman \& Hamadi, 2014). The current study noted that suspension was used on students who had serious offences and that they were made to stay out of school for a specific period of time after which they would report to the school administration when suspension was over. The use of suspension in managing student behavior problems is reflected in the following interview excerpts; "Suspension is used on students who plan a strike, fight, defy teachers and sneak out of school and are persistent in failing to do class assignments." [HOD, 4]

Document analysis guides too established that suspension was used in managing student behavior problems like fighting among fellow students and causing bodily harm, bringing a full matchbox and a packet of condoms to school, issuing threats to the school administration and being found in possession of mobile phones in school.

Findings from HOD 4 and document analysis guides imply that suspension was used in managing student behavior problems. Similarly, Kaguamba and Muola (2010) in Kenya agreed that there were many methods of managing student behavior problems, and suspension was one of them. Vacar (2010) in America too established that In School Suspension program was an effective and necessary tool to help for classroom management. Vacar (2010) further noted that the program was beneficial because it improved attendance and kept students up to pace with very little limitations. However, Bejarano (2014) in Florida does not support the use of suspension and argues that removing students from classroom removes them from meaningful educational opportunities that affect their future and eventual socioeconomic status and further states that exclusionary discipline is not equitable and leaves some students at a marked disadvantage. Similarly, Golomb (2010) in the USA argues that codes of conduct most commonly found in schools rely on exclusionary measures that have been associated with negative student outcome and controversy and those schools need to reconsider their discipline practices and begin to incorporate positive strategies into their policies. Similarly, Macharia, Thinguri and Kiongo (2014) argue that there's need to review the discipline policy with more participation of teachers, the principal and Board of Management Members in the management of discipline.

\section{Concluding Remarks}

The study established that even though alternative corrective measures like guidance and counseling were used in managing student behavior problems, corporal punishment was still in use. This meant that teachers did not abide by Ministry of Education policy on the management of student behavior problems. The study also found out that alternative corrective measures of managing student behavior were not very specific and this made some teachers use some methods that were deemed unfit for the learner. In addition, teachers lacked adequate training on the use of alternative corrective measures.

\section{References}

Afande, O. (2015). Effects of Guidance and Counseling on Pupils in Public Primary Schools in Makadara Primary Schools in Makadara Division of Nairobi Province. Research on Humanities and Social Sciences. Vol, No.5, pgs. 63-77.

Alawo, C. (2011). Effectiveness of Alternative Discipline Strategies in Secondary Schools after the Ban of Corporal Punishment in Bondo District, Kenya. Unpublished Med Thesis, University of Nairobi.

Alemu, Y. (2013). Assessment of the Provisions of Guidance and Counseling Services in Secondary Schools of East Harerege Zone and Hareri Region, Ethiopia. Middle Eastern and African Journal of Educational Research. Vol .4 (3), pp. 28-37.

Aloka, P. and Bojuwoye, O. (2013). Gender Differences in Decisions on Student Disciplinary Behaviors by Disciplinary Panels of Selected Kenyan Secondary Schools. Gender \& Behavior. Asian Social Science, Vol. 9 (10), pp. 43-55. 
Ajibola A., Lukman, L. \&. Hamadi , A. (2014). Disciplinary Measures in Nigerian Senior Secondary Schools: Issues and Prospects. Journal of Research \& Method in Education. Vol .4 (3), pp. 11-17.

Anitra, W. (2013). Middle School Teachers' Perceptions of Discipline. Unpublished PhD. Dissertation, Ohio State University.

Bechuke, L. \& Debella, R. (2012). Applying Choice Theory In Fostering Discipline: Managing and Modifying Challenging Learners Behaviors in South African Schools. International Journal of Humanities and Social Science. Vol 2 (.22), pp. 240-255.

Bejarano, M.(2014).The Role of Race in Zero Tolerance in Exclusionary Discipline. Unpublished PhD Thesis. University of Central Florida Orlando, Florida.

Borkan, B., Cappa, Y.,Figueiredo,C.,\& Loadman, W.E. (2003). Using Rasch Measurement to Evaluate the Organizational Climate Index. Paper Presented on 23rd October at the annual meeting of the Mid-Western educational Research Association, Columbus, $\mathrm{OH}$.

Brown, K. (2013). Challenging Behavior in Secondary School Students: Classroom Strategies for Increasing Positive Behavior. New Zealand Journal of Teachers' Work, Vol. 10 (1), pp. 125-147.

Braun, V. and Clarke, V. (2006). Using thematic analysis in psychology, Qualitative Research, Vol. 3, pp. 77-101.

Busienei, A. (2012). Alternative Methods and Their Efficacy. Journal of Emerging Trends In Educational Research and Policy Studies (JETERAPS) Vol.3 (2) pp.155-164.

Canter, L., \& Canter M. (2001). Assertive discipline: Positive Behavior Management for Today's Classroom. Santa Monica, CA: Canter $\&$ Associates.

Cohen, L., Manion, L \& Morrison, K. (2007). Research Methods in Education. London: Routledge Falmer

Corsine, R. J. (1987). Concise Encyclopaedia of Psychology. New York: John Wiley and Sons Pearson.

Creswel, J.W. (2014). Research Design: Qualitative, Quantitative and Mixed Method Approaches (4th Ed.).Thousand Oaks: CA: Sage Publications

Deidra, M (2013). Teachers' Perceptions and Satisfaction with PBIS in a South East Georgia School District. Unpublished Med. Dissertation, Georgia Southern University.

Eliamani,P.,Mghweno,L. \& Baguma, P. ( 2014). Access to Guidance and Counseling Services and its Influence on School Life, Attitude towards Studies and Career Choice. African Journal of Guidance and Counseling. Vol 1(1) pp.001-015.

Golkar,R., Alavijeh, K., Ghasempoor, A.,Amiri,M and Zarrin, A. (2012).Qualitative Study Styles and Methods of Disciplinary measures used in Middle Schools to Provide Appropriate Guidance. Interdisciplinary Journal of Contemporary Research in Business, Vol 4, NO.2, pp. 766-774.

Golomb, S. (2010). Proactive Disciplinary Consequences in Three Illinois High Schools. Unpublished Phd Dissertation. Loyola University, Chicago.

Ifeoma, R. (2011).Effective classroom management techniques for secondary schools. African Research Review: An International Multidisciplinary Journal, Ethiopia. Vol.5(1) pp. 240-266.

Inkoom, S.A. (2010). Studnets's and Teachers' Perception of Discipline of Adonten Senior High School. Unpublished Med. Dissertation, University of Cape Coast.

Kaguamba, G.\& Muola, J.(2010). Students' Perceptions of the Effectiveness of the Methods Used to Enhance Discipline in Public Secondary Schools in Nyahururu Division, Laikipia West District, Kenya. African Research Review: An International MultiDisciplinary Journal, Ethiopia, Vol. 4 (1), pp. 415-427.

Kavula, J. (2014). Effects of Principals Alternative Disciplinary Methods on Student Discipline in Public Secondary Schools in Kitui County. Unpublished PhD Thesis, University of Nairobi.

Khewu, N. (2012). A Study of Practices In The Alternatives To Corporal Punishment Strategy Being Implemented In Selected Primary Schools In Buffalo City Metro Municipality. Unpublished PhD Thesis, university of Fort Hare.

Kiggundu, H. (2009). The Influence of Discipline Management by Head Teachers on Students' academic Performance in Selected Private Secondary Schools of Busiro County in Wakiso District. Unpublished Med Thesis, Faculty of Education. Makerere University, Uganda.

Kilonzo, J. (2013). Challenges Faced by Headteachers in the Management of Students' Indiscipline in Public Secondary Schools in Lamu County. Unpublished Med. Project, Kenyatta University.

Kindiki, J. N. (2009). Effectiveness of Communication on Students Discipline in Secondary Schools in Kenya. Educational Research and Review, 4 (5): 252-259.

Kipkoech,L.(2014). Alternative Methods to Corporal Punishment In Managing Students Discipline in Secondary Schools: A Case of Bomet District, Kenya. Unpublished Master of Philosophy Thesis, Moi University.

Macharia, J., Thinguri, R. \& Kiongo, P. (2014). An Investigation into the Deputy Principals Preparedness in Discipline Management in Secondary Schools in Kenya. International Journal of Education and Research. Vol 2 (6)pp.199-244.

Makinde, O. (1987). Foundations of Guidance and Counseling. London: Macmillan Publishers.

Marais, P. \& Meier, C. (2010). Disruptive Behaviour in the Foundation Phase of Schooling. South African Journal of Education. Vol.30,p.380-388.

Maphosa,C.\& Shumba, A.(2010) Educators' disciplinary capabilities after the banning of corporal punishment in South African schools. South African Journal of Education, Vol. 30, pp.387-399.

Mohrbutter, T.L. (2011). In-School Suspension: A Qualitative Examination of Assistant Principals' Perceptions. Unpublished Dissertation, North Carolina State University.

Mugabe, J.M. \& Maphosa, D.A. (2013). Methods of Curbing Learner Misconduct In Zimbabwean Secondary Schools. Journal on New Trends in Education and Their Implications. Vol (1), Pp 111-122. 
Muneja, S. (2013). Teacher Experiences of Disciplinary Measures in Tanzania Adventist Secondary School: A Case Study. Journal of Education and Practice, Vol 4, pp, 169-177.

Mwangi, J. (2014). Influence of Alternative Disciplinary Measures on Students Discipline in Public Secondary Schools In Laikipia West District, Kenya. Unpublished Med Thesis, University of Nairobi.

Nakpodia, E, D. (2012) Teachers' disciplinary approaches to students discipline problems in Nigerian secondary schools. Global Journal of Human Social Science, Linguistics \& Education. Volume 12 Issue 11.pp 144-151.

Nassey, C. (2012). Teachers' Use of Classroom Based Management Strategies: A Survey of New Zealand Teachers. Unpublished Med. Thesis, Massey University, Albany.

Ngotho, S \& Zani,P. ( 2014). Impact Of Counseling Methods In Promoting Student Discipline In Public Secondary Schools In Kiambu County, Kenya. Research Journal of Education. Vol 2/ No.2, pp.1-16.

Njogu, N. (2007). Effectiveness of Guidance and Counselling as an Alternative Discipline Method To Corporal Punishment: A Case of Kirinyaga District Primary Schools Kenya. M.ED project in Guidance and Counseling. Egerton Njoro, Kenya.

Nkabinde, S. (2007). Management of Discipline in Primary Schools in Bhekuzulu Circuit. Unpublished M.ED. Dissertation, Tshwane University of Technology, S.A.

Ntuli, L. (2012). Managing Discipline in a Post - Corporal Punishment Era Environment in Secondary Schools In The Sekhukhune School District, Limpopo. Unpublished Thesis, University of South Africa.

Oyinloye, G. (2010). Primary School Teachers' Perception Of Classroom Management and Its Influence On Pupils' Activities. European Journal of Educational Studies 2(3), 305-317.

Raburu, P. A. (2015). Motivation Of Women Academics and Balancing Family And Career. Journal of Educational and Social Research, Vol.5, pg. 359-370.

Rampa, H.S. (2014). Discipline in Schools: Assessing the Positive Alternative Invitational Discipline Approach: World Journal of Education. Vol. 4. Pp.20-29.

Rosenhan, D. L., \& Selignman, M.P. (1995). Abnormal Psychology (Third Edition). New York: Norton and company.

Rothbauer, P. (2008) "Triangulation." In Given, L. (Ed.), "The SAGE Encyclopedia of Qualitative Research Methods. "Sage Publications. pp. 892-894.

Samoei, K.W. (2012). The Role of Guidance and Counseling in Management of Student Discipline in Secondary Schools in Londiani District, Kericho County, Kenya. Unpublished Med Project, Kenyatta University.

Sekuwi, D. \& Naluwemba, F.(2014). Alternatives To Instilling Discipline In Primary Schools During The Post Corporal Punishment Era In Uganda. Global Journal of Human-Social Science, Vol. 14, Issue 4, pgs 16-24.

Simatwa, E. (2012). Management of Student Discipline in Secondary Schools in Kenya, a Case Study of Bungoma County. International Research Journals Vol. 3. (2) pp. 172-189.

Soneson, U. (2005). Ending Corporal Punishment in South Africa, Pretoria: Save the Children Sweden, Regional Office for South Africa.

Suleiman, Q., Hussain, I., Akhtar, Z., (2013). Techniques used by Secondary School Teachers in Managing Classroom Disruptive Behavior of Secondary School Students in District Karak (Pakistan). International Journal of Learning and Development. Vol. 13, (1): $17-28$.

Tungata, M. (2006). Maintaining Discipline in Schools in The Post- Colonial Era. Unpublished MED Thesis, Nelson Mandela Metropolitan University.

Umezimwa, N. \& Elendu, C. (2012). Perception of Teachers towards the use of Punishment in Sancta Maria Primary School. Journal of Education and Practice. Vol 3, No.2, pp. 49-57.

UNICEF, (2001). "Background Paper Regional Expert Meeting on Quality Basic Education, 12-14 February 2001". UNICEF Regional Office for South Asia. Kathmandu.

Vaccar, J. (2010). Teachers' Perceptions Of The In school Suspension Program At Centreville High School. Unpublished Med Thesis, Cedarville University.

Yariv, E. (2012) Principals' management Styles for Coping with discipline problems: Practical and Theoretical aspects. International Review of Social Sciences and Humanities, Vol. 4, No.1 (2012). Pp 74-85.

Yaworski, L. (2012). Corporal Punishment: Schools Ask, "Spare The Rod or Use It?" Unpublished M.ed thesis, Brockport State University of New York.

Yuan, Y. (2014). Teachers' Perceptions and Concerns on the Banning of Corporal Punishment and it's Alternative Disciplines. British Journal of Social Work, Vol. 4, No.1 (2014). 